\title{
Białorusini na Lotwie (1920-1939) oczami dyplomatów polskich w Rydze
}

Powstałe po I wojnie światowej państwo łotewskie miało charakter wielonarodowościowy. Do najliczniejszych grup mniejszościowych należeli m.in. Białorusini. Ludność białoruska zamieszkiwała przede wszystkim ziemie południowo-wschodniego państwa łotewskiego - Łatgalię (dawne Inflanty Polskie). Większość łotewskich Białorusinów stanowili małorolni i bezrolni chłopi, wśród których był bardzo wysoki odsetek analfabetów. Wielu białoruskojęzycznych mieszkańców Łatgalii miało poważny problem z identyfikacją narodowościową. Stan świadomości narodowej miał bezpośredni wpływ na liczebność populacji. Brak wykrystalizowanego poczucia przynależności do tej czy innej narodowości stwarzał urzędnikom łotewskim duże możliwości nadinterpretacji w czasie przeprowadzania powszechnych spisów ludności. Zmiany liczebności ludności białoruskiej w Republice Łotewskiej zostały ujęte w poniższej tabeli.

\begin{tabular}{|c|c|c|c|}
\hline $\mathbf{1 9 2 0}$ & $\mathbf{1 9 2 5}$ & $\mathbf{1 9 3 0}$ & $\mathbf{1 9 3 5}$ \\
\hline $75630(4,74 \%)$ & $38010(2,06 \%)$ & $36029(1,90 \%)$ & $26867(1,38 \%)$ \\
\hline
\end{tabular}

Po zakończeniu I wojny światowej na Łotwie dały się zauważyć przejawy działalności ruchu białoruskiego. Do pierwszych prób życia narodowego Białorusinów w tym kraju dochodzi w okresie walk Łotwy o niepodległy byt państwowy. Trzon ruchu białoruskiego na Łotwie stanowili działacze Białoruskiej Republiki Ludowej (BRL), którzy przybyli tu w 1919 roku. Stosunek władz łotewskich do po- 
lityków BRL był przychylny, co znalazło swe odbicie w nawiązaniu stosunków dyplomatycznych między Łotwą i BRL ${ }^{1}$. Po zawarciu traktatu ryskiego część polityków białoruskich przyjęła obywatelstwo Łotwy i osiedliła się w tym kraju. Wkrótce dołączyła do nich grupa działaczy białoruskich, którzy przyjechali z Polski. Ta nieliczna grupa Białorusinów podjęła się trudu organizacji życia narodowego ludności białoruskiej na Łotwie. Za sprawą tych ludzi Łotwa zamieniła się w jeden z najważniejszych ośrodków białoruskiego ruchu narodowego w okresie międzywojennym. W stosunkowo krótkim okresie powstał szereg stowarzyszeń białoruskich o charakterze społeczno-kulturalnym, oświatowym, sportowym i politycznym; wydawano prasę. Działało również szkolnictwo. Za pierwszą i najbardziej liczącą się organizację białoruską na Łotwie należy uznać stowarzyszenie społeczno-kulturalne „Baćkaŭszczyna” (Ojczyzna) działające w latach 1921-1925. Podejmowano próby działalności politycznej. Należy podkreślić, że temat mniejszości białoruskiej na Łotwie w okresie międzywojennym jest mało zbadany ${ }^{2}$.

1 Zob.: Jēkabsons Ē., Stosunki między Eotwa i Białoruska Republika Ludowa w latach 1919-1921, „Białoruskie Zeszyty Historyczne” 1997, z. 7, s. 49-62.

2 Za pierwszą próbę przedstawienia problematyki dotyczącej mniejszości białoruskiej w Republice Łotewskiej należy uznać pracę K. Jezowitowa (К. Езавітаў, Беларусы ў Латвіi, Ryga 1927). Praca ta odznacza się bardzo dużymi walorami poznawczymi. Nie licząc broszury propagandowej Jana Douhiego (Беларускi нацьыянал-фашызм у Латвіi, Мінск 1934), opracowanie Jezowitowa przez dłuższy czas było jedyną pracą poświęconą Białorusinom na Łotwie. Należy ją jednak traktować raczej jako źródło historyczne, a nie opracowanie naukowe. Powołują się na nią J. Najdziuk i I. Kasiak w swej popularnonaukowej syntezie historii Białorusi (Я. Найдзюк, І. Касяк, Беларусь учора й сяньня, Mińsk 1993, s. 221-228). Współczesna historiografia białoruska na razie nie może się poszczycić bogatą literaturą przedmiotu na temat Białorusinów na Łotwie. Wyjątek stanowią nieliczne prace poświęcone poszczególnym epizodom ruchu białoruskiego w tym kraju oraz niektórym jego postaciom (Крывіцкія руны: Беларускія пісьменнікі Латвii, Mińsk 2003; С. Сахараў, В. Сахарава, Выбраньля творьы, Mińsk 2015; П. Сокал, В. Казлоўская, Вығраныл творы, Mińsk 2016). Na odrębną uwagę zasługują publikacje badaczy łotewskich: Apine I., Baltkrievi Latvijā, Ryga 1995; Jēkabsons Ē., Белорусы в Латвии в 1918-1940 годах, [w:] Беларуская дыяспара 
Relacje pomiędzy działaczami białoruskimi i państwem łotewskim były na ogół poprawne. Demokratyczne ustawodawstwo łotewskie umożliwiło powstanie szkolnictwa białoruskiego i działalność organizacji kulturalno-oświatowych. Władze łotewskie popierały Białorusinów zwłaszcza w pierwszych latach niepodległości, ponieważ traktowano ich jako swoistą przeciwwagę dla Polaków ${ }^{3}$. Z czasem poparcie władz dla strony białoruskiej malało. Władze w Rydze niepokoił fakt, że większość działaczy ruchu białoruskiego w latach dwudziestych znajdowała się pod oddziaływaniem ZSRR, na co miała wpływ polityka korienizacji (,czerwona białorutenizacja”) na Białorusi Sowieckiej. W latach trzydziestych, gdy przez BSRS przetoczył się walec represji stalinowskich przeciwko przedstawicielom kultury, większość działaczy białoruskich na Łotwie zaniechało aktywnej współpracy z Mińskiem. Miejscowy ruch białoruski miał napięte stosunki z pozostałymi mniejszościami narodowymi na Łotwie, przede wszystkim z Polakami i Rosjanami. Wśród czołowych działaczy ruchu białoruskiego na Łotwie należy wymienić przede wszystkim Konstantyna Jezowitowa ${ }^{5}$, Włodzimierza

як пасярэдніца ў дыялогу ичывілізаџый. Матэрыялы ІІІ Міжнароднага кангрэса беларусістай, Mińsk 2001); Казачёнок К., “Белорусский прочесс” в Латвии: обвинение, оправдание, наказание, [w:] Латыии и беларусы: вместе сквозь века. Сборник научных статей, red. М.Г. Каралёў, Мінск 2012, s. 29-42.

${ }^{3}$ Gierowska-Kałłaur J., Stosunek państwa łotewskiego do miejscowych Polaków i Białorusinów w początkach niepodległości łotewskiej, „Studia z Dziejów Rosji i Europy Środkowo-Wschodniej” 2011, t. 46, s. 181-216.

4 Grzybowski J., Савецкая рэчаіснасиь на бачьнах беларускай газеть у Латвіi “Голас Беларуса” (1925-1929 2.), [w:] „Światła masz tyle w sobie...». Ze studiów wschodniosłowiańskich. Księga pamiątkowa dedykowana Profesorowi Aleksandrowi Barszczewskiemu w osiemdziesiąta piata rocznicę urodzin, red. M. Kaczmarczyk, A. Nowacki, M. Sidor, B. Siwek, Lublin 2015, s. 207-222.

${ }^{5}$ Konstantyn Jezowitow (1893-1946), białoruski działacz polityczny i wojskowy, pedagog i poeta. W 1918 r. był ministrem spraw wojskowych w pierwszym rządzie BRL. W 1919-1920 szef misji wojskowo-dyplomatycznej BRL w państwach bałtyckich. Aktywny działacz mniejszości białoruskiej na Łotwie 1920-1944. Redaktor gazety „Hołas Biełarusa”. Inspektor szkół białoruskich. Organizator białoruskiego ruchu młodzieżowego. 
Pigulewskiego $^{6}$, Mikołaja Demidowa ${ }^{7}$, Sergiusza Sacharowa ${ }^{8}$. Byli to ludzie w BRL mający niebagatelne doświadczenia w zakresie pracy politycznej i organizacyjnej. Niekiedy dochodziło między nimi do zatargów i konfliktów o podłożu ambicjonalnym. Pigulewski ściśle współpracował z łotewskimi socjaldemokratami, był członkiem i aktywnym działaczem tej partii. W czasie demokracji parlamentarnej na Łotwie piastował stanowiska państwowe, był m.in. kierownikiem białoruskiego wydziału szkolnego przy Ministerstwie Oświaty. Ogromne zasługi dla rozwoju ruchu białoruskiego na Łotwie położył Jezowitow, redaktor gazety „Hołas Biełarusa” (Głos Białorusina), pierwszego pisma białoruskiego w międzywojennej Łotwie. Działacz ten był niestrudzonym pedagogiem, wybitnym publicystą i utalentowanym badaczem. Nie ulega wątpliwości, że był on również prekursorem białoruskiego życia narodowego na Łotwie. Dał się poznać jako działacz o poglądach bardzo lewicowych. Przynajmniej do 1934 r. pozostawał pod wpływami polityki na Białorusi Sowieckiej. Zajmował bezkompromisowe stanowisko wobec reżimu Ulmanisa. W przeciwieństwie do niego, Demidow po zamachu majowym przyjął bardzo ugodową postawę względem nowych władz. W 1934-1939 był informatorem łotewskiej policji politycznej. Sacharow był znany przede wszystkim z działalności naukowej i publicystycznej.

${ }^{6}$ Włodzimierz Pigulewski (1889-1958), dyplomata BRL, od 1922 r. mieszkał w Dyneburgu. Od 1925 r. kierownik białoruskiego wydziału szkolnego przy Ministerstwie Oświaty. Poseł na Sejm Łotwy (1928-1931) z listy łotewskich socjaldemokratów.

7 Mikołaj Demidow (1888-1967), białoruski działacz wojskowy i polityczny, pedagog. W 1918-1920 brał czynny udział w formowaniu oddziałów białoruskich. W 1918-1919 komendant białoruski Grodna. W 1920 r. w Armii Ochotniczej gen. S. Bułak-Bałachowicza. Od 1922 r. mieszkał na Łotwie. Uczestniczył w organizacji szkolnictwa białoruskiego. Prezes Białoruskiego Towarzystwa Nauczycieli.

${ }^{8}$ Sergiusz Sacharow (1880-1954), białoruski działacz społeczny, badacz folkloru. Od 1921 r. prezes Białoruskiego Towarzystwa Kulturalno--Oświatowego „Baćkauszczyna”, 1922-1925 kierownik białoruskiego wydziału szkolnego przy Ministerstwie Oświaty. W 1925-1932 dyrektor gimnazjum białoruskiego w Dyneburgu. Założyciel Białoruskiej Partii Demokratycznej. 
W wyniku zamachu w maju 1934 r. władzę objął Kārlis Ulmanis, który wprowadził w kraju ustrój autorytarny. Reżim prowadził politykę unifikacji państwa na różnych płaszczyznach. Postanowiono przyśpieszyć proces zespolenia Łatgalii z resztą kraju. Zamierzano tego dokonać z zastosowaniem metody nacisków. Reżim Ulmanisa wyznawał zasadę wypierania wpływów kulturalnych i politycznych mniejszości narodowych. W niepełny miesiąc po zamachu stanu zmieniono ustawę językową. Języki mniejszości narodowych miały zniknąć z użytku w samorządach i instytucjach państwowych. Następnie zmiana ustawy o szkolnictwie położyła kres autonomii szkolnej mniejszości narodowych ${ }^{9}$. Trzeba zaznaczyć, że po przewrocie majowym władze łotewskie traktowały ruch białoruski marginesowo. Uważano, że zagadnienie białoruskie na Łotwie nie istnieje. Wychodzono z założenia, że ruch białoruski w razie potrzeby będzie można spacyfikować, uciekając się do środków administracyjnych ${ }^{10}$. Nie można jednak powiedzieć, że po 1934 r. mniejszość białoruska na Łotwie została całkowicie pozbawiona wszelkich możliwości prowadzenia swej działalności organizacyjnej. Działał m.in. Białoruski Związek Nauczycieli z M. Demidowym na czele.

Na poglądy polityczne przywódców łotewskich Białorusinów w latach trzydziestych wywierała ogromny wpływ ogólna sytuacja międzynarodowa w ówczesnej Europie. Istniejące wśród miejscowych działaczy nastroje odzwierciedlały stan ducha panujący w białoruskim obozie narodowym na kontynencie. W połowie lat trzydziestych nad Europą zawisła groźba nowej wojny. Stwarzało to pewną szansę dla działaczy białoruskich na podniesienie kwestii białoruskiej do rangi międzynarodowej. Nadciągający konflikt przyczynił się do ożywienia środowisk białoruskich w różnych państwach europejskich. Na począt-

\footnotetext{
9 Łossowski P., Kraje baltyckie na drodze od demokracji parlamentarnej do dyktatury: 1918-1934, Wrocław 1972, s. 253-254, 261-263.

${ }_{10}$ Archiwum Akt Nowych (dalej: AAN), Ministerstwo Spraw Zagranicznych, sygn. 477/5328, Raport Poselstwa RP w Rydze, 12 II 1939 r., dot. działalności białoruskiej na Łotwie.
} 
ku prym wiedli działacze białoruscy w Pradze, gdzie mieszkał Wasyl Zacharka, prezes Rady Białoruskiej Republiki Ludowej, białoruskiej niepodległościowej reprezentacji politycznej na uchodźstwie. W 1939 r. w Pradze odbyła się konferencja emigrantów białoruskich z Czech, na której postanowiono, że pierwszym zadaniem Rady BRL ma być nawiązanie ścisłego kontaktu z ośrodkami białoruskimi w Polsce, na Litwie, Łotwie i ZSRR, by skoordynować siły w obliczu nadchodzącego konfliktu międzynarodowego w Europie. Na tym zjeździe Zacharka zaapelował do przywódców diaspory białoruskiej na Litwie i Łotwie o dostarczenie informacji na temat kadry kierowniczej zdolnej do pracy narodowej i organizacyjnej, nie ulegajacej nigdy wptywom sit obcych. W apelu tym czytamy m.in.: Dobrze by było wiedzieć, kto u was może być centralna figura. Proszę was bardzo, ruszajcie się, ruszajcie i jeszcze raz ruszajcie się tak, jak to czyniq inne gnębione narody ${ }^{11}$. Niezadowoleni z istniejącego wówczas ładu wersalskiego działacze białoruscy szukali oparcia wśród czynników obcych, które z rozmaitych względów były zainteresowane utrzymaniem przy życiu ruchu białoruskiego. Ówczesna koniunktura polityczna sprawiła, że większość działaczy białoruskich opowiedziała się za współpracą z III Rzeszą. U schyłku lat trzydziestych coraz więcej działaczy białoruskich wiązało z Berlinem nadzieje na utworzenie białoruskiego państwa narodowego. Świadczy o tym fakt, że 20 kwietnia 1939 r. Zacharka wystosował memoriał do Hitlera zapewniając, iż naród białoruski w petni poprze każda sitę, która pomoże mu zniszczyć to więzienie, w którym zostal zniewolony [...] prowadząc walkę z najbardziej wściektymi wrogami, którymi sa dla niego Rosja i Polska, w celu najszybszego zwycięstwa będzie on z radościa witat nawet najtrudniejsze przemiany na wschodzie Europy ${ }^{12}$. W tym dokumencie polityk białoruski wyraził także

11 AAN, sygn. 477/5328, Raport Ambasady RP w Rydze, z 12 lutego 1939 r., dot. działalności białoruskiej na Łotwie.

12 Gosudarstwiennyj archiw Rossijskoj fiedieracii (Państwowe Archiwum Federacji Rosyjskiej, dalej: GARF), fond (zespół, dalej: f.) 5875, opis (inwentarz, dalej: op.) 1, dieło (teczka, dalej: d.). 21, list (karta, dalej: 1.). 20-29, Memorandum 
nadzieję, że władze III Rzeszy zechcą uwzględnić w czasie wojny przeciwko ZSRR interesy narodu białoruskiego ${ }^{13}$. Podobne nastroje zapanowały wśród łotewskich Białorusinów. Łącznikiem pomiędzy stroną niemiecką a przywódcami łotewskich Białorusinów był dr Eugen von Engelhardt, łatgalski Niemiec, który pracował w Berlińskim Instytucie Badań nad Granicami i Państwami Obcymi. Z racji tego, że uczony miał bogatą wiedzę i rozeznanie w środowisku inteligencji białoruskiej, został radcą do spraw białoruskich Alfreda Rosenberga, szefa Wydziału Zagranicznego NSDAP ${ }^{14}$. W 1938 r. Engelhardt nawiązał kontakty z niektórymi miejscowymi działaczami białoruskimi. Latem 1939 r. na zaproszenie Engelhardta do Berlina wyjechał M. Demidow, prezes Białoruskiego Towarzystwa Nauczycieli. Oficjalnym celem podróży było wygłoszenie szeregu prelekcji i odczytów na temat historii i kultury Białorusi. Podczas pobytu w Niemczech Demidow spotkał się z niektórymi działaczami białoruskimi w Berlinie (Fabianem Akinczycem, Anatolem Szkutko). Łotewski Białorusin odbył rozmowę z prof. Gerhardem von Mende, kierownikiem sekcji białoruskiej w Niemieckim Instytucie Badań nad Problemami Zagranicznymi na Uniwersytecie Berlińskim. Plan podróży przewidywał również spotkanie z Rosenbergiem, do którego jednak nie doszło z niewiadomych powodów. Efektem współpracy Demidowa z Berlinem był wyjazd do Niemiec do grupy polskich studentów i robotników rolnych narodowości białoruskiej w celu szkolenia dywersyjnego ${ }^{15}$.

W. Zacharki do Hitlera, kwiecień 1939 r.; В. Раманоўскі, Саўдзельнікі у злачьнствах, Мінск 1964, s. 20-21.

13 GARF, f. 5875, op. 1, t. 21, k. 29, Memorandum W. Zacharki do Hitlera, kwiecień 1939 r.

14 У. Сакалоўскі, У. Ляхоўскі, Нямеччьна й беларускі наџьянальны рух напярэдадні й у першыя гады Другой Сусьветнай Baйны, „Białoruskie Zeszyty Historyczne" 2000, z. 13, s. 6-7.

15 Latvijas Nacionālā arhīva Latvijas Valsts arhīvs (Państwowe Archiwum Łotwy Narodowego Archiwum Łotwy, dalej: LVA), 1986 fondas (zespół, dalej: f.), 2 apraksts (opis, dalej: apr.), P-10551 lieta (teczka, dalej: 1.), 88-97 lapa (karta, dalej: lp.), Protokół przesłuchania M. Demidowa i W. Korci, 26 XII 1940. 
W przededniu wybuchu II wojny światowej działalność łotewskich Białorusinów zwróciła uwagę Poselstwa RP w Rydze. Spowodowane to było wizytą w Rydze w lutym 1939 r. Jana Stankiewicza, jednego z czołowych polityków białoruskich w Wilnie. Stankiewicz wykonywał polecenie Zacharki i miał zbadać stan diaspory białoruskiej na Łotwie. Celem tej wizyty było także pogodzenie zwaśnionych działaczy białoruskich na Łotwie i nakłonienie ich do utworzenia centrum koordynującego działalność białoruską w tym kraju. Akcja Stankiewicza zaniepokoiła polski MSZ, ponieważ w tym samym czasie zaobserwowano wzmożoną aktywność środowisk białoruskich w innych państwach europejskich (głównie w III Rzeszy). Poselstwo RP w Rydze przygotowało dwa obszerne raporty o stanie ruchu białoruskiego w Republice Łotewskiej ${ }^{16}$. Są to bardzo ciekawe źródła rzucające nowe światło na sytuację ruchu białoruskiego na Łotwie. Źródła te są szczególnie cenne w odniesieniu do wydarzeń po 1934 r., ponieważ wiedza na temat działalności białoruskiej na Łotwie po ustanowieniu reżimu Ulmanisa jest bardzo uboga. Nie ukazywała się wówczas miejscowa prasa białoruska, zaś państwa ościenne nie poświęcały wiele uwagi sprawom białoruskim na Łotwie. Autorzy dokumentu rozpatrują aktywność łotewskich Białorusinów w szerszym kontekście, wpisując ją w nurt aktywności białoruskiej w całej Europie. Raporty zawierają ciekawe i mało dotąd znane informacje na temat kontaktów przywódców łotewskich Białorusinów z ośrodkami ruchu białoruskiego w innych państwach. Niemniej jednak do wielu informacji zawartych $\mathrm{w}$ tych dokumentach należy podchodzić $\mathrm{w}$ dużą rezerwą. Nie sposób oprzeć się wrażeniu, że tekst jest nacechowały pogardą i niechęcią wobec miejscowego ruchu białoruskiego. W wielu przypadkach autorzy mijają się z prawdą. Zdecydowanie należy odrzucić pogląd, jakoby w przededniu przewrotu Ulmanisa wszystkie stowarzyszenia i organizacje białoruskie na Łotwie skupiały zaled-

${ }^{16}$ AAN, sygn.: 477/5328, k. 37-41, 48-50. 
wie 84 członków ${ }^{17}$. Z innych źródeł wiemy, że najbardziej prężnie rozwijająca się organizacja białoruska - Towarzystwo „Biełaruskaja Chata" - zrzeszała w swoich szeregach ok. 600 osób na terytorium całego kraju ${ }^{18}$. Czytając te raporty należy pamiętać, że nie wyszły one spod pióra osób zachowujących bezstronność w ocenie łotewskich Białorusinów. Przedłożony uwadze czytelników dokument należy traktować jako obraz ruchu białoruskiego na Łotwie widziany oczami strony konkurencyjnej względem ruchu białoruskiego. Nie ulega wątpliwości, że na treść dokumentów miały wpływ stosunki polsko-białoruskie na Łotwie, które nie układały się pomyślnie. Miejscowi działacze polscy i białoruscy znajdowali się w stanie ostrego konfliktu, u podstaw którego leżały względy wynikające z różnicy interesów. Powstały po I wojnie światowej ruch białoruski rozwijał się w opozycji do polskości. W swoich zasadniczych założeniach organizacyjnych i programowych miejscowi przywódcy białoruscy i polscy przyjmowali postawy ofensywne, podejmując działania zmierzające do rozszerzenia swej ekspansji kulturowej na wówczas jeszcze w dużym stopniu nieunarodowioną wieś łatgalską. Płaszczyzną, na której odbywała się rywalizacja polsko-białoruska, było przede wszystkim szkolnictwo oraz wybory do parlamentu i samorządów. W prasie natomiast obrzucano się wzajemnymi oskarżeniami i obelgami. Nie powinna więc dziwić duża ilość krytycznych uwag zawartych w dwóch dokumentach, które zamieszczamy poniżej. Pierwszy z nich to raport Poselstwa RP w Rydze na temat najważniejszych ośrodków ruchu białoruskiego w przededniu II wojny światowej, zaś drugi w całości poświęcony jest sytuacji Białorusinów na Łotwie w okresie międzywojennym.

\footnotetext{
${ }^{17}$ AAN, sygn. 477/5328, Raport Poselstwa RP w Rydze, 12 II 1939 r., dot. działalności białoruskiej na Łotwie.

${ }^{18}$ Jēkabsons Е., Белорусы в Латвии..., ор.cit., s. 61.
} 


\section{DOKUMENT NR 1 \\ Ośrodki ruchu białoruskiego}

W Pradze odbyła się konferencja zamieszkałych w Czechosłowacji Białorusinów. Z referatem o sytuacji politycznej wystąpił b. przewodniczący Rady Białoruskiej Narodowej Republiki W. Zacharko. Treść tego referatu sprowadza się do następujących spraw:

1) obecnie zagadnienie białoruskie ponownie stało się aktualne, gdyż idące wypadki mogą sprzyjać powstaniu niezależnego państwa białoruskiego;

2) ruch białoruski związany jest z ruchem ukraińskim;

3) najbliższym zadaniem Rządu Białoruskiego to nawiązanie kontaktu z masami białoruskimi w ZSSR, Polsce, Łotwie i Litwie;

4) dla zrealizowania tego kontaktu należy natychmiast uzyskać środki finansowe. W związku z tym uchwalono na konferencji rezolucję o utworzeniu specjalnego funduszu.

Wyciąg z protokołu zjazdu:

„Biorąc pod uwagę, że sprawa narodowego i państwowego wyzwolenia Białorusi wchodzi obecnie w fazę nowych historyczno-politycznych wydarzeń, co wymaga od wszystkich Białorusinów zajęcia czynnej pozycji w tej akcji - konferencja postanowiła powołać do życia w Pradze, jako w centrze białoruskiej emigracji fundusz białoruski. Fundusz ten stworzony zostanie z dobrowolnych ofiar i obowiązkowego opodatkowania wszystkich Białorusinów zamieszkałych w Czechosłowacji. Dobrowolne datki i ofiary, jak również ich wysokość zależy wyłącznie od patriotyzmu i dobrej woli ofiarodawców. Mogą one być jednorazowymi datkami, jak również i periodycznymi. Obowiązkowe opodatkowanie się staje się narodowym przymusem każdego Białorusina mieszkającego w Czechach. Wysokość tego podatku równać się winna dziennemu zarobkowi w miesiącu. 
Do zarządu Funduszu wybrano: W.[asyla] Zacharkę i dr. J.[ana] Jermaczenkę ${ }^{1}$. Do Komisji Rewizyjnej: inż. [Aleksandra] Rusaka², dr Wituszkę i K. Buśkę. Przekazy pieniężne kieruje się pod adresem: Praga I, koło Prasznej Bramy nr 1, róg Czaletnej”. Protokół konferencji kończy się następującą rezolucją: „Konferencja wzywa wszystkich braci Białorusinów zamieszkałych w Czechosłowacji do zrozumienia obecnego momentu i do wykonania w pełnej mierze tych narodowych obowiązków, jakie nałożone są na emigrację. Zjazd żywi nadzieję, że białoruska emigracja w Czechach, rekrutująca się prawie wyłącznie z białoruskiej emigracji przyczyni się swoją pracą i pomocą materialną do wyzwolenia narodu białoruskiego spod okupacji".

W dniu 18 I b.r. Zacharko wystosował list do b. ministra spraw zagranicznych Republiki Białoruskiej [Jazepa] Woronki, zamieszkałego obecnie w Ameryce. Pismo to było adresowane do „Białorusko-Amerykańskiego Związku”. O sobie Zacharko pisze: „Ja, jako przewodniczący Rady Białoruskiej Republiki Ludowej uważam się obecnie za przedstawiciela całej Białorusi”. Zacharko wzywa do jedności i zgody, i prosi o zasilenie Funduszu ofiarami. Przytoczony poniżej wyjątek wskazuje na małą wiarę Zacharki w możliwości szybkiej realizacji jego planów. „O ile w Europie Wschodniej wypadki zatrzymały się w swoim rozwoju na czas dłuższy, to ja, jakby dodatek do tego listu postaram się przyjechać do was osobiście".

29.XII.1938 r. Zacharko zwraca się listownie do łotewskich Białorusinów z prośbą o udzielenie informacji:1)w sprawie działalności organizacyjnej i 2) o poszczególnych działaczach ,zdolnych do pracy

\footnotetext{
${ }^{1}$ Jan Jermaczenka (1894-1980), białoruski działacz polityczny. W 1921 r. był konsulem BRL w Konstantynopolu i w krajach Bałkańskich. Wiceminister spraw zagranicznych BRL. Od 1922 r. mieszkał w Pradze, gdzie brał czynny udział w działalności diaspory białoruskiej. W 1939 r. wywarł presję na W. Zacharkę, by ten wystąpił do władz niemieckich z memorandum lojalnościowym zawierającym propozycję współpracy.

${ }^{2}$ Aleksander Rusak, działacz białoruski. Przed wojną mieszkał w Pradze, potem w Polsce.
} 
narodowej i organizacyjnej, posiadających talent kierowniczy, nie ulegających nigdy wpływom obcych sił. Dobrze by było wiedzieć, kto u was może być centralną figurą. Proszę was bardzo ruszajcie się tak, jak to czynią inne pognębione narody".

Listy Zacharki wywołały na Łotwie wśród Białorusinów silne wrażenie. „Bolszewizujący” Jezowitow powraca do czynnego życia społecznego, wstępuje do Białoruskiego Związku Nauczycieli, na czele którego stoi Demidow i nosi się z zamiarem wydawania w Rydze pisma w języku białoruskim. W tej sprawie kontaktuje się z b. soc.-dem. posłem Pigulewskim. Bardzo charakterystyczny kompromis Pigulewski/Jezowitow, do roku 1934 zwalczający siebie nawzajem. Również i wileńscy Białorusini interesują się żywiej swoją sytuacją. Zawiadomili oni Jezowitowa, Pigulewskiego i Jezowitowa (trzej liderzy białoruscy w Łotwie), że w dn. 31 I przyjedzie do Rygi zamieszkały w Wilnie dr Jan Stankiewicz celem wygłoszenia referatu o ruchu białoruskim w Polsce.

Dnia 12 II Stankiewicz opuścił Łotwę. Przez czas jego pobytu odbywały się narady, przy czym Stankiewicz, b. nauczyciel Demidowa, wpływał na niego, aby ten się usunął z kierownictwa Związku Nauczycieli. Demidow oskarża się, że jest on zanadto dobrze widziany u Łotyszów, że jest niezdecydowany i że ,gubi sprawę”.

Rząd łotewski do całego ruchu białoruskiego odnosi się ze spokojem. O jakimkolwiek zagadnieniu białoruskim na Łotwie się nie mówi. Istnieje tylko grupa aktywnych Białorusinów w kołach b. związku nauczycielskiego (w związku nauczycielskim byli również nie nauczyciele, lecz i sympatycy reprezentowanego przez nauczycieli białoruskich kierunku). Rząd jest przekonany bez względu na zaoferowane ostatnio przejawy aktywności wśród Białorusinów, że ruch ten nie ma silnych podstaw w masach łatgalskich i że będzie można łatwo go zlikwidować środkami policyjnymi.

Następni działacze, z których składa się kierownictwo i z którymi łotewscy Białorusini podtrzymują kontakty: 


\section{Ameryka: Woronko ${ }^{3}$ \\ Gereniuk}

\section{Wilno: Łuckiewicz Antoni}

Stankiewicz Iwan

Szutowicz ${ }^{4}$

Akinczyc (kontakt zerwany) ${ }^{5}$

Olechnowicz ${ }^{6}$

Dubikowski, inż.

Umiastowski $^{7}$

Iliaszewicz ${ }^{8}$

Ostorowski $^{9}$

Kowno:

Duszewski ${ }^{10}$

\footnotetext{
${ }^{3}$ Jazep Waronka (1991-1952), jeden z uczestników proklamowania BRL, minister spraw białoruskich w litewskiej Tarybie (1918-1920), prezes Gromady Białoruskiej w Kownie (1922-1923). W 1923 r. wyemigrował do USA, gdzie kontynuował działalność białoruską. Brał udział w pracy Białorusko-Amerykańskiej Rady Narodowej, redagował gazetę „Biełorusskaja Tribuna”.

${ }^{4}$ Alfons Szutowicz, działacz białoruski w Wilnie, uczestników ruchu studenckiego, zwolennik chadecji.

${ }^{5}$ Fabian Akinczyc (1886-1943), działacz białoruski w II RP, organizator i przywódca Białoruskiej Partii Narodowosocjalistycznej.

${ }^{6}$ Franciszek Olechnowicz (1883-1944), białoruski publicysta, pisarz, dramaturg. Autor szeregu sztuk teatralnych. W 1935 r. w Wilnie wydał wspomnienia $W$ szponach GPU, przetłumaczone na kilka języków świata.

${ }^{7}$ Franciszek Umiastowski(1882-1940),jeden zprekursorów ruchu białoruskiego, redaktor naczelny pierwszej gazety białoruskiej „Nasza Dola” (1906), w okresie międzywojennym działacz białoruski o poglądach polonofilskich. Redaktor gazety „Biełaruski Dzien””.

${ }^{8}$ Teodor Iljaszewicz (1910-1948), białoruski działacz polityczny i społeczny, dziennikarz i poeta.

${ }^{9}$ Radosław Ostrowski (1887-1976), działacz białoruski, dyrektor gimnazjum białoruskiego w Wilnie (do 1936 r.).

${ }^{10}$ Klaudziusz Duż-Duszewski (1891-1959), polityk BRL, architekt, działacz białoruski na Litwie Kowieńskiej.
} 
Burysewicz $^{11}$

Matar

Sirotka ${ }^{12}$

Pliskaczewski ${ }^{13}$

Jakowluk $^{14}$

Bojew, adwokat ${ }^{15}$

Zeiglit

Zurankow, agronom

$\underline{\text { Praga }}$

Zacharka $^{16}$

Wituszka, dr

$\underline{\text { Paryż }}$

Białoruska grupa robotnicza ${ }^{17}$

\section{AAN, Sztab Główny, t. 357, k. 208-210.}

\footnotetext{
${ }^{11}$ Wasyl Barysowicz, członek Białoruskiego Towarzystwa Kulturalno-Oświatowego w Kownie i Centrum Białoruskiego na Litwie.

${ }^{12}$ Ignacy Sirotka, członek Białoruskiego Towarzystwa Kulturalno-Oświatowego w Kownie i Centrum Białoruskiego na Litwie.

${ }^{13}$ Anatol Pliskaczewski (1911-1980), w 1932-1939 pracował jako agronom w powiecie wileńsko-trockim, nie wykazywał większej aktywności politycznej.

${ }^{14}$ Szymon Jakowiuk (1881-1973), działacz białoruski, poseł na Sejm II RP (19221923), od 1924 r. mieszkał w Kownie, współpracował z wywiadem sowieckim.

15 W. Bojew, uczestnik ruchu białoruskiego na Litwie. W 1920-1921 wchodził w skład Najwyższej Rady Obrony Litwy. Członek ministerstwa spraw białoruskich w rządzie litewskim. W 1921-1922 był łącznikiem pomiędzy władzami BRL i Tarybą. Członek Białoruskiej Partii Ludowych Socjalistów. Był radcą prawnym w MSZ Litwy. Później pracował jako prawnik w poselstwie sowieckim w Kownie. ${ }^{16}$ Wasyl Zacharka (1877-1943), minister finansów w pierwszym rządzie BRL, w 1928-1943 prezes Rady BRL na uchodźstwie.

${ }^{17}$ Chodzi o Wspólnotę Robotników Białoruskich we Francji (założoną w 1930 r.) z Mikołajem Abramczykiem i Leonem Rydlewskim na czele.
} 


\section{DOKUMENT NR 2 \\ Białorusini na Lotwie}

Termin „Białorusin” po raz pierwszy użyty został z chwilą przybycia do Rygi misji z ramienia Białoruskiej Republiki Ludowej ${ }^{18}$. Na czele misji stał pułkownik Konstanty Borysowicz Ezowitow (czyt. Jezowitow).

Ezowitow, ur. w Dyneburgu, po ukończeniu instytutu nauczycielskiego wstąpił do Pawłowskiej szkoły wojennej w Mińsku. Tam też wstąpił do białoruskiej socjal-federacyjnej partii, a po powstaniu Białoruskiej Republiki Ludowej mianowany został pułkownikiem.

W Rydze Ezowitow zorganizował białoruskie towarzystwo „Batkiwszczyna"19, dokąd początkowo wstępowali Żydzi. Obywatelstwo białoruskie i paszporty wydawał sam Ezowitow. Zaznaczyć przy tym należy, że posiadanie paszportu białoruskiego uwalniało od służby wojskowej w armii łotewskiej. Po oswobodzeniu Dyneburga Ezowitow udał się do Łatgalii. W Dyneburgu założył on również oddział „Batkiwszczyny”. W roku 1921 oddziały także „Batkiwszczyny” istnieją w Rzeczycy i Lucynie. Do organizacji tej wstępują w Łatgalii również Rosjanie, których Łotysze chętnie wówczas traktują jako Białorusinów. Niemałą rolę grały również względy osobistej kariery. Liczba członków na terenie łatgalskim osiąga w tym czasie cyfrę 300 osób.

Dla celów organizacyjnych Ezowitow rozporządzał większą sumą pieniędzy. Pierwszym krokiem Ezowitowa poza kreowaniem towarzystwa było zorganizowanie ,,białoruskich kursów nauczycielskich", dokąd przyjmowani byli z braku odpowiednich kandydatów także ludzie o wykształceniu zaledwie elementarnym. Z uwagi na

\footnotetext{
${ }^{18}$ Chodzi o Misję Wojskowo-Dyplomatyczną BRL działającą na Łotwie i w Estonii w latach 1919-1921.

${ }^{19}$ Powinno być „Baćkaŭszczyna”. Pełna nazwa: Białoruskie Towarzystwo Kulturalno-Oświatowe „Baćkaŭszczyna”.
} 
to, iż ukończenie tych kursów poniekąd gwarantowało uzyskanie posady, wstępowali na nie również Polacy i Rosjanie. Na kursach tych nauczycielami byli najczęściej Białorusini importowani z Polski i Litwy: tak np. Budźka ${ }^{20}$ pochodził z Wilna, Andrzej Jakubieckij ${ }^{21}$, b. gławkom białoruskiej armii ludowej z Mińska, Miadziałko Paulina ${ }^{22}$, córka organisty z Głębokiego, Spućko z białoruskiego batalionu na Litwie $^{23}$, Kazek ${ }^{24}$ z Litwy itd. Zorganizowano szybko całą sieć białoruskich szkół. Przy Ministerstwie Oświaty został powołany do życia tzw. białoruski oddział ${ }^{25}$, na czele którego stał S. Sacharow; Ezowitow zaś, przyjąwszy obywatelstwo łotewskie, mianowany został inspektorem tych szkół.

Sergiusz Sacharow, uważający się jeszcze w czasach carskich za Białorusina, był do roku 1914 nauczycielem w Aleksandrowskim gimnazjum w Witebsku; po wojnie mianowany został dyrektorem gimnazjum w Lucynie.

Po utworzeniu całego szeregu szkól podstawowych wzięto się do organizowania szkolnictwa średniego. Tak więc powstało białoruskie gimnazjum w Dyneburgu i prywatne - towarzystwa „Batkiwszczyna" w Lucynie. Nauczycielami w tych szkołach byli pow. wymienieni Kazek, Miadziałko i Jakubeckij, również niejaki Iwan

${ }^{20}$ Edward Budźka, działacz białoruski, pedagog. Jako pierwszy przybył na Łotwę na zaproszenie Jezowitowa w celu organizowania szkolnictwa białoruskiego. Został mianowany kierownikiem I kursu nauczycielskiego w Dyneburgu.

${ }^{21}$ Andrzej Jakubiecki (1892-?), białoruski działacz wojskowy i polityczny, członek Białoruskiej Komisji Wojskowej (1919-1921), dowódca oddziałów białoruskich podczas powstania antybolszewickiego w powiecie słuckim w 1920 r. W 1922 1925 mieszkał na Łotwie, gdzie brał udział w organizacji szkolnictwa białoruskiego. 22 Paulina Miadziołka (1893-1974), białoruska artystka i pedagog. W 1922-1925 mieszkała na Łotwie, brała udział w działalności szkolnictwa białoruskiego. W 1925 r. wyjechała do Mińska.

${ }^{23}$ Zapewne chodzi o Samodzielny Batalion Białoruski w składzie armii litewskiej, który istniał w 1919-1923.

${ }^{24}$ Sergiusz Kazeka, nauczyciel gimnazjum białoruskiego w Lucynie.

${ }^{25}$ Chodzi o białoruski wydział szkolny, który powstał w październiku 1922 r. przy Ministerstwie Oświaty. 
Kraskowksi ${ }^{26}$ - socjalista (w roku 1919 przewodniczący ukraińskiej Rady na Kaukazie, potem jakiś czas zamieszkały w Wilnie). Ponadto, w skład grona nauczycielskiego wchodzili: Mikołaj Demidow (oficer z batalionu białoruskiego na Litwie - ukończył w roku 1918 jakieś kursa w Wilnie) oraz Włodzimierz Pigulewski (studiował widział historyczno-filologiczny na uniwersytecie w Petersburgu, oficer artylerii na froncie rumuńskim, przez krótki okres czasu w szeregach białej armii, później jako oficer w batalionie białoruskim na Litwie. Z czasów studenckich członek partii socjal-demokratycznej).

W roku 1922/23 ludność Łatgalii nie przyznawała się do narodowości białoruskiej, nauczyciele szkół podstawowych określili się jako Białorusini ze względów oportunistycznych. Natomiast pewne bardziej uświadomione jednostki, przygotowane przez poprzedni staż w partiach socjalistycznych, rozpętały agitację, czując przy tym protekcję rządu łotewskiego, który obawiał się u ludności łatgalskiej rusofilskich, czy też polonofilskich tendencji.

Białoruska grupa Łatgalii nawiązała kontakt z białoruskimi kołami w Pradze, Litwie, Polsce i ZSRR. W lecie 1923 roku odbył się w Dyneburgu zjazd działaczy białoruskich na Łotwie, którzy rozważali problem pewnych posunięć taktycznych. Za sprawą łatgalskich Białorusinów zorganizowano w gimnazjum dyneburskim dla zbiegów białoruskich z zagranicy do ZSRR rodzaj schroniska. W ciągu jednego tylko półrocza przez gimnazjum w Dyneburgu przewinęło się około 40 partyzantów z Litwy i około 10 z Polski (w tej liczbie agent $\mathrm{z}$ ramienia posła Taraszkiewicza $)^{27}$.

\footnotetext{
${ }^{26}$ Jan Kraskowski (1880-1955), białoruski działacz polityczny, pedagog. W $1918 \mathrm{r}$. był w rządzie Ukraińskiej Republiki Ludowej. W 1920 r. prezes Białoruskiego Komitetu Narodowego w Wilnie. W 1922 r. na zaproszenie Jezowitowa przybył do Łotwy w celu pomocy w organizowaniu szkolnictwa białoruskiego. Dyrektor gimnazjum białoruskiego w Dyneburgu. W 1925 r. wyjechał do Białorusi Sowieckiej.

${ }^{27}$ Kontakty pomiędzy działaczami białoruskimi na Łotwie a wywiadem sowieckim wymagają głębszych badań.
} 
Na wspomnianym zjeździe zebrali się Białorusini o rozmaitych odcieniach politycznych za wyjątkiem „,prowokatorów z Polski” za jakich uważano: Aleksiuka ${ }^{28}$, senatora Bogdanowicza ${ }^{29} \mathrm{i}$ płk. Ładno$\mathrm{wa}^{30}$. Mińsk reprezentowany był przez Michalewicza. Na zjeździe skrytykowano działalność Ezowitowa, który szeroko rozbudował szkolnictwo białoruskie, nie troszcząc się zupełnie o jego poziom. W związku z tym postanowiono zwrócić baczniejszą uwagę na sprawę uświadomienia nauczycieli i uczniów. Zarządzono przy tym „czystkę” w gronie nauczycielskim i w towarzystwie „Batkiwszczyna”. Ta ostatnia utworzyła w międzyczasie filię w Krasławiu, na czele której stanął nauczyciel Krasniewicz i filię w gminie pustyńskiej, gdzie prezesem został niejaki Klagit. W Rydze „Batkiwszczyna” liczyła około 20 członków, urzędników wydziału białoruskiego przy Ministerstwie Oświaty i robotników w Czerwonej Dźwinie (dzielnica Rygi). W Łatgalii „Batkiwszczyna” liczyła około 500 członków. „Czystkę” oparto na następujących zasadach: 1) sporządzono specjalną listę nauczycieli, których lojalność w stosunku do ruchu białoruskiego budziła zastrzeżenia i przy ad hoc zarządzonych egzaminów utrącono ich jako nieposiadających odpowiednich kwalifikacji; 2) w łonie „Batkiwszczyny" przeprowadzono ostrą kampanię przeciwko elementom rusofilskim, w wyniku której pewna liczba członków prezentowana przez dyrektora szkoły w Dyneburgu Sadowskiego musiała wystąpić $\mathrm{z}$ towarzystwa.

W jesieni 1923 r. - dzięki tym posunięciom - liczba nauczycieli z 137 spadła do 74, a liczba członków „Batkiwszczyny” z 500 do 120. Osoby, które tak gwałtownie zmuszone zostały do wystąpienia

\footnotetext{
${ }^{28}$ Paweł Aleksiuk (1892-?), działacz białoruski w II RP o poglądach polonofilskich. ${ }^{29}$ Wiaczesław Bogdanowicz (1878-1939), białoruski działacz polityczny i religijny, senator II RP, prezes Białoruskiego Demokratycznego Zrzeszenia Prawosławnego. ${ }^{30}$ Eugeniusz Ładnow, białoruski działacz polityczny i wojskowy, minister obrony i minister spraw zagranicznych BRL, należał do odłamu polonofilskiego w ruchu białoruskim, potem mieszkał w Niemczech.
} 
z organizacji białoruskich stały się ich zaciętymi wrogami. Do tego okresu należy zaliczyć powstanie grupy „białoruskich monarchistów”.

Wśród białoruskich nauczycieli istniało nieliczne ugrupowanie ,bezpartyjnych”, składające się ze stałych mieszkańców Łotwy, mających bliskie kontakty z Łotyszami i b. właścicieli ziemskich na Białorusi Sow.[ieckiej]. Ugrupowanie to zostało nietknięte z uwagi na wspomniane kontakty w „górze”. Tę grupę „,nabrali” Kraskowski i Jakubeckij na tworzenie niezależnej republiki białoruskiej, usiłując za pośrednictwem „bezpartyjnych” wydobyć większe fundusze na te cele. Rozmowy swoje z „,bezpartyjnymi” tak Jakubeckij, jak i Kraskowski trzymali w głębokiej tajemnicy przed socjalistami. Jeden z ,bezpartyjnych” w związku z pow.[yższą] akcją wyjechał do Monachium, skąd sygnalizował wkrótce, że fundusze zostaną udzielone z „Wyższej Rady Monarchistycznej” (?) ${ }^{31}$. Postawiono przy tym szereg warunków, jak nienaruszalność prywatnych majątków ziemskich, przyjazne ustosunkowanie się do Rosjan antybolszewików itd. Monachijskie ugrupowania dawały podobno pieniądze $\mathrm{z}$ tym również zastrzeżeniem, że powstanie wzniecone będzie najpierw na terytorium Rosji Sowieckiej, wówczas kiedy Jakubeckij planował wywołanie ruchawki wyłącznie na terenie Polski. Później Jakubeckij tłumaczył się, że liczył on na przebywających z Polsce partyzantów, a więc na Muchę $^{32}$, Chmarę ${ }^{33}$ itd. Demaskując się, że ruch białoruski propago-

${ }^{31}$ Istnieje prawdopodobieństwo, że niektórzy działacze białoruscy utrzymywali kontakty z Bractwem Prawdy Rosyjskiej, tajną organizacją o orientacji monarchistycznej działającą na emigracji w okresie międzywojennym.

${ }^{32}$ Mucha-Michalski - pseudonim używany przez organizatorów i dowódców partyzantki komunistycznej w województwach północno-wschodnich II RP w 19211925 .

${ }^{33}$ Wiaczesław Razumowicz-Chmara (ok. 1886-?), działacz wojskowy. Weteran I wojny światowej. W 1918 r. był doradcą hetmana Pawła Skoropackiego. W 1919 r. przeniósł się do Grodna, gdzie zaangażował się w działalność organizacji białoruskich. W 1920 r. był komendantem Grodna podczas okupacji miasta przez bolszewików. Jesienią $1920 \mathrm{r}$. znalazł się na Litwie Kowieńskiej, gdzie z polecenia władz litewskich zajął się organizacją białoruskich oddziałów partyzanckich do walki z wojskami polskimi. Wstąpił do Samodzielnego Batalionu Białoruskiego w składzie armii litewskiej. W $1921 \mathrm{r}$. 
wany przez niego nie będzie nosił charakteru antybolszewickiego, spowodował wystąpienie ugrupowania bezpartyjnego z ciekawym memorandum do gen. Radzińsza. Ten ostatni, reprezentując kierunek propolski, zaczął naciskać na sfery rządowe celem zastosowania innej polityki wobec łotewskich Białorusinów. Pewne zmiany w składzie rządu, stanowisko gen. Radzińsza ${ }^{34}$ wobec problemu białoruskiego i akcja Polski w r. 1924 wywołały masowe areszty wśród Białorusinów. W roku 1925 odbył się proces, w rezultacie którego wszyscy oskarżeni zostali uniewinnieni (w tej liczbie Ezowitow, który przesiedział jednak w areszcie śledczym około roku ${ }^{35}$. „Batkiwszczyna” została mimo wszystko rozwiązana a część działaczy, jak Kraskowski $\mathrm{i}$ inni, wysiedleni do Rosji Sow.[ieckiej]. Zwinięto również gimnazjum w Lucynie i nauczycielskie kursy w Dyneburgu. W tym czasie organizować zaczęto w Rydze szkołę białoruską, wokół której Białorusini poczęli się gromadzić.

Ryga przyciągała Białorusinów ze względu na socjalistyczne rządy w tym mieście. To też korzystając, w szybkim tempie uruchomiono dwie szkoły podstawowe, szkołę dla dorosłych, kurs nauczycielski, a nawet czyniono przygotowania do stworzenia gimnazjum. W mieście rozwiązanej „Batkiwszczyny” utworzono szereg organizacji, jak „Chata Białoruska”, „Ruń, Kasę pożyczkowo-oszczędnościową, kooperatywę, Teatr białoruski i inne, a także reaktywowano Związek

dowodził IV grupą partyzancką, która przygotowywała antypolskie akcje dywersyjne na Grodzieńszczyźnie i Wileńszczyźnie. W 1923 r. należał do sztabu Związku Strzelców Białoruskich. Podjął współpracę w OGPU. W 1924 r. został zwolniony z armii litewskiej i wyjechał do Gdańska. W następnych latach podejmował próby kontaktów z wywiadem polskim, łotewskim i sowieckim. W lutym 1926 r. wziął udział w konferencji białoruskiej w Gdańsku.

${ }^{34}$ Pēteris Valdemārs Radziņš (1880-1930), łotewski działacz wojskowy i polityczny. Uczestnik I wojny światowej. Szef sztabu armii łotewskiej w czasie walk o niepodległość. W 1924-1928 dowódca sił zbrojnych Łotwy.

${ }^{35}$ Proces białoruski odbył się 2-4 kwietnia 1925 r. w sądzie okręgowym w Dyneburgu. Na ławie oskarżonych znalazło się ośmiu działaczy białoruskich, którym zarzucano uprawianie działalności separatystycznej (działania na rzecz oderwania Łatgalii od państwa łotewskiego). Wszyscy oskarżani zostali uniewinnieni. 
Nauczycielski założony w Dyneburgu w r. 1922. W wyborach do sejmu przeszedł z listy białoruskiej Pugulewski, podczas gdy Ezowitow, który opuścił szeregi partii socjal-federalistów, poniósł ze swoją listą generalną klęskę (Ezowitow należał już wówczas do partii „Niezależnych łotewskich socjalistów”). Według danych komisji wyborczej, Pigulewski otrzymał szereg głosów komunistycznych, co zgadzało się z instrukcjami łotewskiej K[komunistycznej] P[artii ${ }^{36}$. Korzystając z funkcji poselskich, Pigulewski przejął w swe ręce sprawy szkolnictwa białoruskiego, rozwinął szeroką agitację na rzecz socjaldemokratów, wciągając do tej partii $80 \%$ białoruskich nauczycieli i rozpoczął walkę z socjalistami niezależnymi Ezowitowa. Walka ta przerwana została w parę tygodni później. Na skutek akcji Pigulewskiego Ezowitow został aresztowany. Ezowitow zostaje później przez pewien czas bez pracy, do tego okresu należy odnieść współpracę Ezowitowa z Sowietami. Został on wówczas nawet korespondentem kilku wydawnictw białoruskich w Mińsku i jeździł często do ZSRR. Ezowitow otrzymywał kilka razy większe przekazy pieniężne z Ameryki od Woronki, b. ministra Białoruskiej Republiki Ludowej. Ustalono także, że i Pigulewski otrzymuje pieniądze w związku z tym rozeszła się wersja, że podtrzymuje on kontakt z pewnym polskim urzędem, dowodów na to jednak nie było.

W przeddzień przewrotu Ulmanisa w roku 1934 sytuacja przedstawiała się następująco. Centrem ruchu białoruskiego była Ryga, gdzie istniały 3 ugrupowania toczące między sobą walkę: 1) socjał-demokraci z Pigulewskim na czele, 2) socjaliści niezależni i komuniści z Ezowitowym w charakterze przywódcy i 3) grupa bezpartyjnych z Demidowym. W Łatgalii białoruskie nauczycielstwo sympatyzowało z grupami pierwszą i drugą. Młodzież wiejska wychowana w szkołach białoruskich była nastrojona radykalnie. Siłę Białorusinów oceniać należało wówczas liczbą inteligentów wzgl. liczbą osób zorganizo-

\footnotetext{
${ }^{36}$ Informacja o poparciu kandydatury przez komunistów nie znajduje potwierdzenia w źródłach.
} 
wanych w szeregu towarzystw społecznych i politycznych. Da to w wyniku liczbę 84 osób na dzień 15.V.1934. Jeśli chodzi o masy liczba Białorusinów w ogóle nie jest dokładnie znana ze względu na fałszowaną i naciąganą statystykę. Podczas spisu ludności mieszkańcy Łatgalii podawali swoją narodowość jako: katolicy lub prawosławni i ,tutejsi”. Według danych oficjalnych w roku 1920 Białorusinów było: 75 630, w roku 1925 - 38 000, w 1930 - 36 029, w 1935 - 26867.

W związku z przewrotem Ulmanisa odniesiono się do białoruskich robotników niższej kategorii i małorolnych, jak do elementu niepewnego. Z nauczycielami postąpiono tak, jak w ogóle z socjalistami, tj. w sposób radykalny, za wyjątkiem małej grupy Demidowa. Pisulewski i Jezowitow osadzeni zostali w obozie odosobnienia w Lipawie, lecz wkrótce na skutek choroby ich uwolniono (Pigulewski - ostry katar żołądka, Ezowitow - ischias). Obaj zobowiązali się wstrzymać od jakiejkolwiek akcji politycznej. Po 15 maja rozwiązane zostały wszystkie organizacje białoruskie z uwagi na to, że członkowie zarządów tych organizacji byli socjalistami. Ocalał tylko związek nauczycieli białoruskich, gdzie prezesem był wspomniany Demidow (bezpartyjny). Jednocześnie zostały zamknięte wzgl. zamienione na tzw. mieszane - szkoły białoruskie za wyjątkiem szkół w Rydze i Dyneburgu. Część nauczycieli przeszło na emeryturę, część przeniesiono do szkół mieszanych, których kierownictwo powierzono Łotyszom. Emeryturę otrzymali Demidow, Pigulewski i po dłuższych staraniach Ezowitow. Część nauczycieli zwolniono ze służby, a rekrutująca się spośród ludności wiejskiej zachowała w sercu nienawiść do rządów Ulmanisa, który pozbawił ich chleba.

Pigulewski i Ezowitow w międzyczasie, nie zrywając kontaktów ze swoimi wyznawcami, pracują dalej. Pigulewski prowadzi nadal linię socjal-demokratyczną i podtrzymuje związki z łotewskimi socjalistami oraz Białorusinami w Polsce. Komunikuje się również w sposób tajemniczy z Moskwą, skąd otrzymuje książki naukowe do jakiejś zamierzonej dysertacji. Być może, że pośredniczą w tym 
wypadku Torgpredstwo, czy Połpredstwo. Odwiedzają go również towarzysze partyjni, których instruuje w sposób następujący: „konieczną jest obecnie pozycja wyczekująca, niewątpliwie historyczne wypadki, których ofiarą padną Polska i Litwa, dadzą okazję do dalszej walki. Należy więc tylko przygotowywać się, aby na terytorium wspomnianych państw powołać do życia Republikę Białoruską. Z pomocą pośpieszy Związek Radziecki, gdyż w jego interesie leży, żeby powstało państwo buforowe, które bronić będzie Sowiety przed polską agresją".

W przeciwieństwie do wyczekującego stanowiska Pigulewskiego, Jezowitow stara się działać bardziej aktywnie. Nawiązuje on kontakt z Mińskiem, jak również z Białorusinami w Wilnie, Grodnie, Kownie, Pradze i w Ameryce. Będąc z przekonania socjalistą Ezowitow wyciąga zręcznie w swojej działalności moment narodowy na plan pierwszy, czym jedna sobie część zwolenników Pigulewskiego. Rzuca hasło: w imię Białorusi, czy jest ona komunistyczna, czy faszystowska czy inna.

Od maja 1934 r. Białorusini grupują się około 3 przywódców: Pigulewskiego, Ezowitowa i Demidowa. Ezowitow walczy z Pigulewskim o dusze swoich ziomków. Ezowitow występuje również przeciwko Pigulewskiemu na łamach białoruskich pism za granicą, oskarżając go o polonofilstwo albo wręcz nazywając ,polskim agentem", pomimo że nie ma na to żadnych dowodów poza starymi nieuzasadnionymi plotkami. Demidow, bezpartyjny, lojalny w stosunku do Łotwy, usiłuje forsować kierunek łotewsko-państwowy i wykorzystuje dla tego celu jedną białoruską organizację Związek Nauczycielski. Dlatego też tak Pigulewski, jak i Ezowitow starają się go w oczach Białorusinów zdyskredytować jako łotewskiego agenta. Jeszcze w roku 1934 Ezowitow stara się o poparcie u Niemców. Istnieją poszlaki, że otrzymał z Gdańska pieniądze. W roku 1935 Ezowitow szuka związków z ukraińską organizacją „Prowid”. Według posiadanych tutaj informacji - niesprawdzonych - organizacja taka powstała 
w Niemczech. W 1935 r. powstał jednak między jej kierownictwem a władzami niemieckimi konflikt w konsekwencji czego powstał projekt przeniesienia sztabu tej organizacji do Litwy. W kwietniu 1935 roku odbyła się w Kownie konferencja „Prowidu”, w której uczestniczyło dwóch przedstawicieli z Łotwy. W latach 1935-1938 działalność Ezowitowa ogranicza się do agitacji w Łatgalii, dokąd on i jego zwolennicy wyjeżdżają co lato na urlop.

W maju 1938 r. Pigulewski zwołał zebranie łotewskich socjaldemokratów (nielegalnych) z Lepnem i Lorencem na czele (b. posłowie do Sejmu) dla wyjaśnienia stosunku łotewskich socjaldemokratów do jego osoby, a zwłaszcza do kierunku, jaki on w problemie białoruskim reprezentuje. Wszyscy zaproszeni upoważnili go do indywidualnego występowania na tym odcinku.

\section{Ruch białoruski}

W związku z niesnaskami panującymi pomiędzy poszczególnymi ugrupowaniami wśród tutejszych Białorusinów, Praga poleciła wileńskiemu nauczycielowi Janowi Stankiewiczowi udać się do Rygi, aby wyjaśnić definitywnie sytuację i zbadać, kto może odegrać kierowniczą rolę wśród Białorusinów na Łotwie. Według tych dyrektyw Stankiewicz przybył do Rygi w dniu 9.II z wycieczką zorganizowaną przez „Orbis”. O jego przyjeździe byli już uprzedzeni tutejsi dwaj leaderzy Pigulewski i Ezowitow. Ezowitow poinformował o tym trzeciego z leaderów Demidowa, proponując mu zorganizowanie spotkania. Te same kroki poczynił Pigulewski za pośrednictwem kierownika szkoły w Rydze Syćka. Specjalnego powitania jednak Demidow nie urządził, wyszedł natomiast sam na dworzec, zabierając Stankiewicza do swego prywatnego mieszkania. Stankiewicz zawiadomił telefonicznie o swoim przyjeździe Ezowitowa, który z miejsca poradził nie korzystać z gościnności Demidowa i przenieść się do hotelu, gdyż w przeciwnym razie „Demidow kontrolować będzie wszelkie rozmowy”. Stankiewicz zastosował się do rad Ezowitowa. S. odwiedził także Pigulewskiego. W międzyczasie 
Stankiewicza odwiedziło szereg nauczycieli białoruskich. Wieczorem dnia następnego Stankiewicz udał się do Demidowa, którego namawiał do usunięcia się od jakiejkolwiek działalności polityczno-społecznej. 10 lutego w czasie obrad związku nauczycielskiego Stankiewicz obwinił Demidowa o naruszenie dyscypliny i załamanie linii ,jednolitego frontu białoruskiego" przeciw czemu Demidow z płaczem usprawiedliwiał się. Trzecia rozmowa na ten sam temat przeprowadzona została w dniu 11 lutego. W trakcie rozmowy Stankiewicz instruował, jaką taktykę winni prowadzić Białorusini wobec Łotyszów. W rzeczywistości słowa Stankiewicza były wyraźnym oskarżeniem Demidowa. Wskazał on, że nieliczna inteligencja nie powinna rozdrabniać swoich sił, lecz skupić się wokół osoby „Führera”. Za takiego S. uważa Pigulewskiego - według Stankiewicza - człowieka z dużym doświadczeniem i taktem, byłego posła, tj. człowieka popularnego (należy nadmienić, że Pigulewski wszedł do sejmu głosami nie Białorusinów, lecz socjaldemokratów przy poparciu sfer komunistycznych). Stankiewicz opuścił 12 lutego Rygę.

Stankiewicz przywiózł na Łotwę w ilości 30-40 egzemplarzy kalendarza białoruskiego. Podczas kontroli celnej kalendarz został skonfiskowany, gdyż wykryto w nim fotografię Marksa.

Akcja Stankiewicza wywołała zdziwienie w tut. Ministerstwie Spraw Wewnętrznych, gdyż posiadał on dotychczas opinię człowieka z „grupy Łuckiewicza” (Wilno), tj. zwolennika współpracy z miejscowymi władzami. Za takiego uchodził on podczas swego pobytu w Rydze w roku 1931 czy 1932, kiedy to wszedł w kontakt z licznymi profesorami tutejszego Uniwersytetu Łotewskiego (Blese, Endzelinsz).

Aktywność przywódcy łotewskich Białorusinów Pigulewskiego

W wychodzącej w Wilnie białoruskiej gazecie „Front Białoruski” (nr 4) zamieszczony został artykuł p.t. Tajemnicze wieści biorący za podstawę korespondencję „Ilustrowanego Kuriera Codziennego” z dnia 10 lutego p.t. Brednie o Wielkiej Białorusi, według którego 
w Łotwie istnieje silny ruch białoruski. Trudno jest stwierdzić, czy autorem artykułu w IKC jest korespondent z Łotwy, czy też nie - tutaj jednak w związku z powyższym snuje się następujące przypuszczenia:

1) Po podróży na Łotwę wileńskiego Białorusina Stankiewicza lojalni na Łotwie Białorusini (grupa Demidowa) pozbawieni zostali wszelkich wiadomości z Pragi. Praga skierowuje obecnie (koniec lutego, początek marca - przyp. poselstwa) swoją korespondencję do Pigulewskiego, którego traktuje - bez dostatecznych ku temu powodów - jako wodza Białorusinów na Łotwie.

2) 11 marca Pigulewski obchodził swoje imieniny, w związku z czym zaprosił do siebie prawie wszystkich białoruskich nauczycieli. Kolacja przeciągnęła się do godz. 6 rano, co związane było z dużymi wydatkami, które pokrył z pieniędzy otrzymanych od Stankiewicza.

3) W prywatnychlistach(doZejdlinaw Kownie, do Łuckiewicza ${ }^{37}$ w Wilnie) Pigulewski daje do zrozumienia, że on reprezentuje ruch białoruski na Łotwie.

4) Oczywiście w interesie Pigulewskiego leżało rozpowszechnienie za granicą wiadomości o narodzinach ruchu białoruskiego na Łotwie, stąd też wniosek: nie wykluczone, że Pigulewski jest inicjatorem notatki zamieszczonej w IKC. Pigulewski sprawia wiele kłopotów władzom łotewskim. Podaje się on za przyjaciela gen. Balodisa ${ }^{38}$, który znał Pigulewskiego z czasów wspólnej pracy w komisjach sejmowych. Bolodis nazywa go nie inaczej, jak tylko ,prochwost” i ,mierzawiec”. Łatwowiernych jednak jest sporo, którzy wierzą w opowiadania P[igulewskiego]. I tak np. Pigulewski niedawno opowiadał, że łotewski gabinet ministrów roztrząsa problem białoruski na szerokiej płaszczyźnie, włącznie

\footnotetext{
37 Chodzi o Antoniego Łuckiewicza, znanego działacza białoruskiego w Wilnie, dyrektora Muzeum Białoruskiego i prezesa Białoruskiego Towarzystwa Naukowego. ${ }^{38}$ Jānis Balodis (1881-1965), łotewski polityk i działacz wojskowy. Naczelny dowódca armii łotewskiej w okresie walk Łotwy o niepodległość. Minister wojny (1931-1940) i wicepremier (1938-1940). Współorganizator zamachu Ulmanisa w $1934 \mathrm{r}$.
} 
do wydzielenia pewnych gmin dla przyszłej Białorusi. Stwierdzono oczywiście, że temat ten nie był nigdy poruszany na posiedzeniu rady ministrów.

Grupa Demidowa - biorąc pod uwagę, że zagraniczna prasa nic lub zbyt mało wie o życiu Białorusinów zamieszkałych na Łotwie zdecydowała się podjąć próbę wydawania miesięcznika. Oficjalnym wydawcą ma zostać artysta-malarz Mironowicz ${ }^{39}$, a redaktorem Meżeckij. Nazwa miesięcznika „Życie Białorusinów na Łotwie”.

${ }^{39}$ Piotr Mironowicz (1902-1990), malarz białoruski, absolwent Łotewskiej Akademii Sztuk Pięknych, członek Białoruskiego Towarzystwa Nauczycieli. 